\title{
PENGARUH POLUTAN TAKLARUT TERHADAP KETAHANAN ISOLATOR (Studi Kasus PLTU Molotabu)
}

\author{
Agung anwar ${ }^{1}$, L.M. Kamil amali ${ }^{2}$, yasin mohamad ${ }^{3}$ \\ ${ }^{123}$ Prodi Teknik Elektro Fakultas Teknik Universitas Negeri Gorontalo \\ E.mail : anwaragung467@gmail.com, kamilamali@ung.ac.id, yasinmohamad@ung.ac.id
}

\begin{abstract}
ABSTRAK
Penelitian ini bertujuan untuk memperoleh informai mengenai tegangan lewat denyar dan arus bocor yang diakibatkan oleh iklim serta polusi pembakaran batu bara yang menyebabkan adanya pelapisan polutan dipermukaan isolator. Metoda pemberian lapisan polutan pada permukaan isolator dengan cara menyemprotkan polutan pada permukaan isolator dengan beberapa kondisi pengujian. Metode pegujianya dengan cara diberikan tegangan tinggi sampai terjadi tegangan lewat denyar. Data hasil pengukuran memperlihatkan bahwa, terdapat hubungan yang signifikan antara polutan yang dilapisi pada permukaan isolator dan ESDD yang melekat pada permukaan isolator. Hasil penelitian dapat disimpulkan bahwa dari beberapa kondisi pengujian, maka pada kondisi kering takberpolutan nilai tegangan lewat denyar paling tinggi dan pada kondisi basah perpolutan nilai tegangan lewat denyar paling rendah.
\end{abstract}

Kata kunci : tegangan lewat denyar, isolasi pinpost, polutan, NSDD

\section{PENDAHULUAN}

Masalah utama dalam pendistribusian enargi listrik yang sering terjadi kegagalan dalam saluran transmisi maupun distribusi adalah, adanya tegangan lewat denyar dan arus bocor yang melalui isolator yang melalui isolator sebagai isolalsi utama antara bagian yang bertegangan dengan tanah melalui tiang penyangganya.

Sehingga dapat dikatakan tidak dapat terpenuhinya pelayanan kontinyuitas, dalam pendistribusian energi listrik ke konsumen. Salah satu dari kegagalan yang terjadi dikarenakan adanya pengotoran pada permukaan isolator ataupun terjadinya keretakan mekanis pada isolator.

Isolator selalu berhubungan dengan udara luar, maka banyak faktor yang dapat mengakibatkan isolator tersebut tidak berfungsi dengan baik, diantaranya pengaruh dari polusi udara luar yang mengandung garam. Sehingga dapat megakibatkan terjadinya penumpukan partikel-partikel pengotor yang megandung garam dan debu pasir pantai pada permukaan isolator, yang 
Jambura Journal of Electrical and Electronics Engineering (JJEEE)

diakibatkan dari hembusan udara pantai atau keadaan disekitarnya.

Kondisi PLTU Molotabu yang dekat dengan bibir pantai, pegunungan serta polusi hasil pembakaran batu bara untuk proses pemanasan boiler telah menyebabkan polusi pada jaringan PLTU khusunya pada isolator jaringan transmisinya. Pada kasus PLTU molotabu, polusi ini jadi lebih berat di karenakan lokasinya juga berdekatan dengan jalan trans yang tiap harinya di lalui banyak kendaraan roda dua maupun roda empat.

Masalah utama pada polusi ini adalah terbentuknya lapisan polutan pada permukaan isolator sdistribusi. Dengan terbentuknya lapisan polutan pada isolator ini dapat mengakibatkan terjadinya lewat denyar sehinga akan menggangu fungsi isolator sebagai isolasi listrik (pemisah antara konduktor dan tiang konduktor).

\section{METODE PENELITIAN}

Penelitian ini dilaksanakan mulai dari bulan maret 2018 sampai dengan bulan april 2018 di Lab. Tegangan Tinggi Teknik Elektro Universitas Negeri Gorontalo.
Penelitian dilakukan untuk membandingkan hasil tegangan lewat denyar dari isolator uji. Pengujian tegangan lewat denyar terdiri dari pengujian isolator dalam keadaan bersih dan terpolusi sebelum dan sesudah di basahi. Pengujian tegangan lewat denyar dilakukan dengan menaikan tegangan secara bertahap hingga tercapai peristiwa lewat denyar pada rangkaian yang ditunjukan gambar 1 .

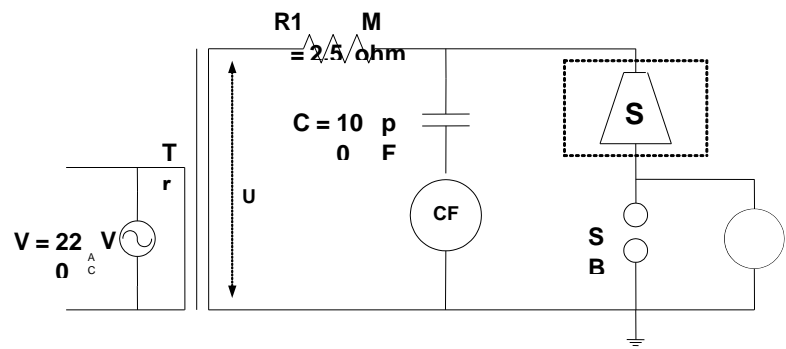

Gambar 1 Skema pegukuran arus bocor pada isolator uji

Keterangan gambar

$\operatorname{Tr} \quad$ : Trafo tegangan tinggi, 220V/100 $\mathrm{kV}$

C : Kapasitor tegangan tinggi, 100 $\mathrm{pF} / 100 \mathrm{kV}$

R1 : Tahanan pelindung, $10 \mathrm{MOhm}$

SB : Sela bola untuk proteksi tegangan lebih, jarak 2,5 mm

$\mathrm{mA}$ : Amperemeter digital bolak-balik

S : Sampel uji (isolator uji)

$\mathrm{CF}$ :Alat ukur tegangan puncak $\mathrm{Chubb}$ \& Fortesque 
Pengujian isolator dilakukan dalam empat kondisi :

1. Kondisi bersih atau belum terkontaminasi oleh polutan.

2. Kkondisi bersih basah dimana permukaaan isolator dibasahi dengan air destilasi (air murni).

3. Kondisi kering berpolutan.

4. Kondisi basah berpolutan, dimana isolator diberikan polutan diambil dari PLTU yang telah tercampur dengan air destilasi.

\section{HASIL DAN PEMBAHASAN}

Pegujian kondisi bersih kering pada isolator uji $20 \mathrm{kV}$ tipe pin post

Pada pegujian ini, isolator diuji dalam keadaan permukaan bersih dan kering yang mensimulasikan kondisi isolator pada saat permukaannya belum terkontaminasi polutan dan berada dalam kondisi kering.

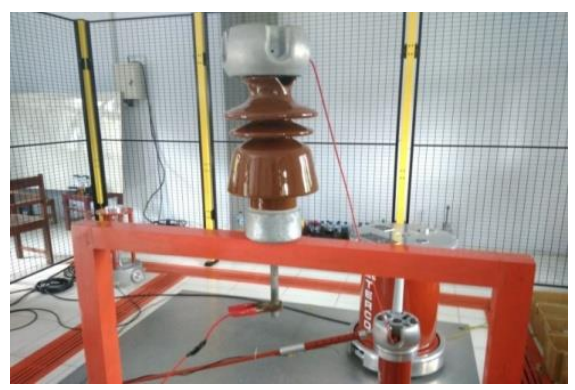

Gambar 2 Pegujian isolator dalam kondisi kering bersih $20 \mathrm{kv}$ tipe pin post
Adapun hasil pegujian dapat dilihat pada tabel 2 dan hubungan antara tegangan lewat denyar terhadap konduktifitas arus bocor isolator uji tipe pin post pada kondisi pegujian bersih dan kering.

Tabel 2 Hasil pengujian konduktivitas permukaan isolator uji pin post $20 \mathrm{kV}$ kondisi bersih kering

\begin{tabular}{|c|c|c|}
\hline \multirow{2}{*}{ NO } & \multicolumn{2}{|c|}{ Kering Bersih } \\
\cline { 2 - 3 } & $\mathbf{V}(\mathbf{k V})$ & $\mathbf{I}(\mathbf{m A})$ \\
\hline 1 & 70.8 & 47.7 \\
\hline 2 & 70.18 & 48.8 \\
\hline 3 & 70.71 & 49.2 \\
\hline Rata -rata & 70.56 & 48.56 \\
\hline
\end{tabular}

\section{Pegujian kondisi bersih basah pada} isolator uji $20 \mathrm{kV}$ tipe pin post

Pada pegujian ini, dalam keadaan ini isoloator diuji dalam keadaan bersih kemudian di basahkan dengan cara pembasahan yaitu menyemprotkan air destilasi sebanyak $50 \mathrm{ml}$ secara merata pada permukaan isolator sebagai simulasi dari butiran-butiran air pada saat hujan 


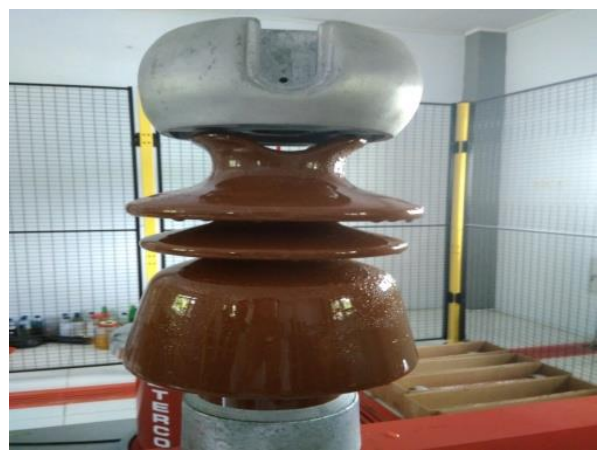

Gambar 3 Pegujian isolator dalam kondisi basah bersih $20 \mathrm{kV}$ tipe pin post

Adapun hasil pengujiannya dapat dilihat pada tabel 3 dan hubungan antara tegangan lewat denyar terhadap konduktifitas arus bocor isolator uji $20 \mathrm{kV}$ tipe pin post pada kondisi pegujian bersih dan basah.

Tabel 3 Hasil pengujian konduktivitas permukaan isolator uji pin post $20 \mathrm{kV}$ kondisi basah bersih

\begin{tabular}{|c|c|c|}
\hline \multirow{2}{*}{ NO } & \multicolumn{2}{|c|}{ Basah Bersih } \\
\cline { 2 - 3 } & $\mathbf{V}(\mathbf{k V})$ & I (mA) \\
\hline 1 & 64.65 & 46.4 \\
\hline 2 & 65.4 & 46.9 \\
\hline 3 & 65.67 & 47.2 \\
\hline Rata -rata & 65.14 & 46.83 \\
\hline
\end{tabular}

Pegujian kondisi terpolusi kering pada isolator uji $20 \mathrm{kV}$ tipe pin post (sampel polutan diambil dari PLTU Molotabu)

Pada pengujian ini isolator $20 \mathrm{kV}$ tipe pin post dalam keadaan terkontaminasi polutan yang diambil dari PLTU
Molotabu dan kondisi isolator dalam keadaan kering. Kondisi ini mensimulasikan kondisi isolator dilapangan khususnya di PLTU Molotabu dan daerah sekitarnya yang banyak terpolusi dengan pegoprasian PLTU itu sendiri dan keadaan alam sekitarnya.

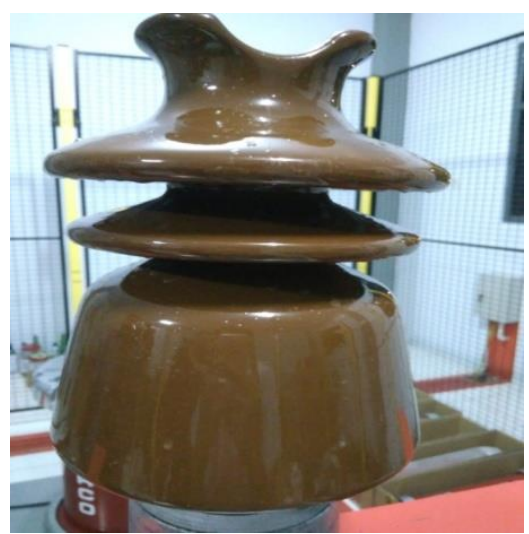

Gambar 4 Pegujian isolator dalam kondisi kering berpolutan $20 \mathrm{kV}$ tipe pin pos

Adapun hasil pengujiannya dapat dilihat pada tabel 4 dan hubungan antara tegangan lewat denyar terhadap konduktifitas arus bocor isolator uji $20 \mathrm{kV}$ tipe pin post pada kondisi pegujian kering berpolutan. 
Tabel 4 Hasil pengujian konduktivitas permukaan isolator uji pin post $20 \mathrm{kV}$ kondisi kering berpolutan

\begin{tabular}{|c|c|c|}
\hline \multirow{2}{*}{ NO } & \multicolumn{2}{|c|}{ Kering Beerpolutan } \\
\cline { 2 - 3 } & $\mathbf{V}(\mathbf{k V})$ & $\mathbf{I}(\mathbf{m A})$ \\
\hline 1 & 62.73 & 41.3 \\
\hline 2 & 62.97 & 41.6 \\
\hline 3 & 63.3 & 41.9 \\
\hline Rata -rata & 63 & 41.6 \\
\hline
\end{tabular}

Pegujian kondisi terpolusi basah pada isolator uji $20 \mathrm{kV}$ tipe pin post (sampel polutan diambil dari PLTU Molotabu)

Pada pengujian ini, isolator uji $20 \mathrm{kV}$ tipe pin post dalam keadaan terkontaminasi dengan polutan dari PLTU molotabu yang dilarutkan kedalam air destilasi kemudian disemprotkan pada permukaan isolator secara merata dan isolator tersebut dalam keadaan basah.

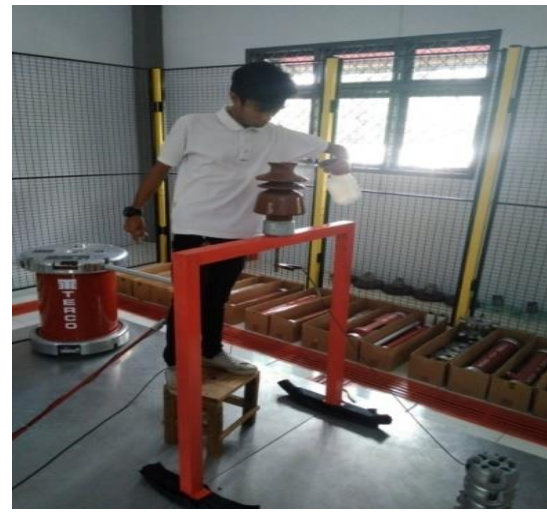

Gambar 7 Pegujian isolator dalam kondisi terpolusi basah $20 \mathrm{kV}$ tipe pin post
Adapun hasil pengujiannya dapat dilihat pada tabel 5 dan hubungan antara tegangan lewat denyar terhadap konduktifitas arus bocor isolator uji $20 \mathrm{kV}$ tipe pin post pada kondisi pegujian terpolusi dan basah.

Tabel 5 Hasil pengujian konduktivitas permukaan isolator uji pin post $20 \mathrm{kV}$ kondisi basah berpolutan

\begin{tabular}{|c|c|c|}
\hline \multirow{2}{*}{ NO } & \multicolumn{2}{|c|}{ Basah Berpolutan } \\
\cline { 2 - 3 } & $\mathbf{V}(\mathbf{k V})$ & $\mathbf{I}(\mathbf{m A})$ \\
\hline 1 & 50.7 & 36.3 \\
\hline 2 & 53.3 & 37.3 \\
\hline 3 & 53.56 & 37.5 \\
\hline Rata -rata & 52.52 & 37.03 \\
\hline
\end{tabular}

\section{KESIMPULAN}

Polutan tak larut merupakan salah satu polutan isolator yang mempegaruhi kemampuan ataupun ketahanan isolator sebagai isolasi listrik melalui kemampuannya menyerap air yang menerpanya. Dari hasil analisa data yang diperoleh dari pengujian yang telah dilakukan, maka dapat ditarik beberapa kesimpulan sebagai berikut :

1. Besaran rata-rata tegangan lewat denyar di permukaan isolator uji $20 \mathrm{kV}$ 
tipe pin post pada kondisi kering bersih $70.56 \mathrm{kV}$. Sedangkan pada kondisi basah bersih adalah $65.14 \mathrm{kV}$.

2. Besaran rata-rata tegangan lewat denyar di permukaan isolator uji $20 \mathrm{kV}$ tipe pin post pada kondisi kering berpolutan $63 \mathrm{kV}$. Sedangkan pada kondisi basah berpolutan adalah $52.52 \mathrm{kV}$.

3. Besaran rata-rata arus bocor di permukaan isolator uji $20 \mathrm{kV}$ tipe pin post pada kondisi kering bersih 46.83 mA. sedangkan pada kondisi basah bersi adalah $46.83 \mathrm{~mA}$.

4. Besaran rata-rata arus bocor di permukaan isolator uji $20 \mathrm{kV}$ tipe pin post pada kondisi kering berpolutan 41.6 mA. sedangkan pada kondisi basah berpolutan adalah $37.03 \mathrm{~mA}$.

\section{DAFTAR PUSTAKA}

[1] Amali Kamil Mohamad Lanto, 2012 “Analisis Pengujian Arus Bocor Line Post Insulator $70 \quad \mathrm{kV}$ yang Terkontaminasi Polutan Industri”.

[2] Jatmiko, Asy'ari H. 2003. “Tegangan Flashover Pada Bahan Isolator Resin Epoksi (DGEBA) yang Terpengaruh oleh Polutan Garam Parangtritis”.
[3] SPLN 10-3B: 1993. "Tingkat Intensitas Polusi sehubungan dengan Pedoman pemilihan Isolator”. Jakarta: Departemen Pertambangan dan Energi, Perusahaan Umum Listrik Negeri.

[4] Suyanto,muhammad, 2011. "Akibat penumpukan kontaminasi udara di permukaan isolator pada saluran distribusi $20 \mathrm{kV}$ dapat mengakibatkan rugi daya listrik",Seminar elektrik,informatics,and its education.

[5] Milan Jones \& Syahrawardi, 2016. "analisis Pengaruh Polutan Pada Isolator Kaca Terhadap Distribusi Tegangan Isolator rantai”.

[6] Suysnto Muhammad, 2010. "Pengujian Isolator Pin-Post $20 \mathrm{KV}$ Terkontaminasi Garam Mengakibatkan Arus Bocor Flashover Pada Permukaan".

[7] Setiaji, Dwi E Muhammad ,dkk, 2012. "Pengujian tegangan flashover dan arus bocor pada isolator $20 \mathrm{kv}$ berbahan resin epoksi silane kondisi basah dan kering”.

[8] Bonggas L. Tobing \& Mustafriend Lubis, 2008, “Hubungnan Intensitas Polusi isolator jaringan distribusi Sumatera Utara dengan Jarak Lokasi Isolator dari Pantai”. 
Volume 1 Nomor 2 Juli 2019

ISSN : 2654-7813

Jambura Journal of Electrical and Electronics Engineering (JJEEE)

[9] Syahrawardi, Alfonso Manogari

Siregar,2015. "Pengaruh Hujan

Terhadap Tegangan Lewat Denyar

Isolator Piring Terpolusi”. 